\title{
Evaluation of the molluscicidal and Schistosoma mansoni cercariae activity of Croton floribundus extracts and kaurenoic acid
}

\author{
Janaina M. Medina, ${ }^{1}$ Juliana L. B. Peixoto, ${ }^{1}$ Adriano A. Silva, ${ }^{1}$ Shirani K. Haraguchi, ${ }^{1}$ \\ Dina L. M. Falavigna, ${ }^{2}$ Maria L. M. Zamuner, ${ }^{3}$ Maria H. Sarragiotto, ${ }^{1}$ Gentil J. Vidotti*,1 \\ ${ }^{1}$ Departamento de Química, Universidade Estadual de Maringá, Avenida Colombo 5790, \\ 87020-900 Maringá-PR, Brazil, \\ ${ }^{2}$ Departamento de Análises Clinicas, Universidade Estadual de Maringá, Avenida Colombo 5790, \\ 87020-900 Maringá-PR, Brazil, \\ ${ }^{3}$ Departamento de Farmácia e Farmacologia, Universidade Estadual de Maringá, Avenida Colombo 5790, \\ 87020-900 Maringá-PR, Brazil
}

\begin{abstract}
RESUMO: “Avaliação das atividades moluscicida e cercaricida (Schistosoma mansoni) dos extratos de Croton floribundus e do ácido caurenóico". Extratos de Croton fluribundus (Euphorbiaceae), ácido caurenóico e dois derivados do ácido caurenóico foram avaliados como moluscicida, cercaricida e também foi verificada a letalidade destas amostras frente a larvas de Artemia salina Leach. Nestes ensaios foram observadas significantes atividades moluscicida e cercaricida associadas a uma reduzida toxicidade frente ao camarão de água salgada.
\end{abstract}

Unitermos: Biomphalaria glabrata, Croton floribundus, Artemia salina, ácido caurenóico, Schistosoma mansoni, cercárias.

\begin{abstract}
Lethality of the extracts of Croton floribundus (Euphorbiaceae), a medicinal plant from south Brazil, and of the kaurenoic acid, an isolated compound, and two of its derivatives against adult Biomphalaria glabrata snails, Schistosoma mansoni cercariae and Artemia salina Leach. brine shrimp larvae are reported. Both extracts and the isolated compound showed significant molluscicidal and cercaricidal activities and reduced toxicity in brine shrimp assays.
\end{abstract}

Keywords: Biomphalaria glabrata, Croton floribundus, Artemia salina, kaurenoic acid, Schistosoma mansoni, cercariae.

\section{INTRODUCTION}

Schistosomiasis is a parasitic disease and endemic disease. It affects millions of people in Africa and South America (Bilia et al., 2000). In Brazil, it affects over 8 million people and about 30 million live in hazard areas due to the presence of infected snails. Schistosomiasis may damage visceral organs, especially the liver, posing risk to life. The parasitary species in Brazil, Schistosoma mansoni, causes the disease popularly known as "xistose" or "barriga d'água". There are different kinds of schistosomiasis, but in all cases, the reproductive cycle involves aquatic snails. The parasite multiplies into hundreds of cercariae that can penetrate the intact human skin of those who are exposed to infected waters after leaving the snails (Marston \& Hostettman, 1993). Chemotherapy is a general strategy for schistosomiasis control; but another more interesting is one that interrupts the disease vital cycle by snail's or cercariae's elimination.

The use of plants with molluscicidal properties is simple, inexpensive, and appropriate for the local control of the snail vector (Marston \& Hostettman, 1993). Since the discovery of highly potent saponins in Phytolacca dodecandra (Phytolaccaceae) berries (Marston \& Hostettman, 1993), naturally occurring molluscicides have received considerable attention and the number of reports on the use of plant-derived molluscicides has increased considerably (Marston \& Hostettman, 1993; Oliveira et al., 2006; Sousa et al., 2008).

The phytochemical investigation of Croton floribundus (Euphorbiaceae), a tree commonly known as "capixingui" or "tapixingui", led to the isolation of kaurenoic acid (2\% in dried barks). Croton floribundus is a medicinal plant used as an anti-inflammatory (Correa, 1984). Kaurenoic acid (1) is known to exhibit biological activities, including antimicrobial, cytotoxic, antiinflammatory, and antiprotozoal activities (Ghisalberti, 1997). In the present work, we describe the molluscicidal activity against adult Biomphalaria glabrata snails, cercaricidal activity and the general toxicity of the methanol bark extract, the ethanol and hexane leaf 
extracts of Croton floribundus and some isolated diterpene, kaurenoic acid (1) to brine shrimp.

\section{MATERIAL AND METHODS}

\section{Plant material}

Croton floribundus was collected in Maringá, PR in August 2001 and authenticated by the Herbarium, HUM, Department of Botany, Universidade Estadual de Maringá, Paraná, Brazil (sheet no. 8 406).

\section{Preparation of extracts}

Dried leaves (1200 g) were ground into a coarse powder and macerated in hexane (A) and in an ethanol sequence $(\mathbf{B})$. Both extracts were dried under reduced pressure and freeze-dried (yields of $90 \mathrm{~g}$ of $\mathbf{A}$ and 175 $\mathrm{g}$ of $\mathbf{B})$.

Dried barks of Croton floribundus (2800 g) were ground into a powder and macerated in methanol. The extract was dried under reduced pressure and freezedried (yield of $400 \mathrm{~g}$ of C).

\section{Isolation of kaurenoic acid (1)}

A portion of $100 \mathrm{~g}(\mathbf{C})$ was submitted to silica gel column chromatography (FLUKA) with hexane, hexanedichloromethane, and dichloromethane-ethyl acetate elution. Five fractions, A-E, were isolated. Fraction B gave pure $\mathbf{1}$ (2 g) on crystallization from methanol.

\section{Bioassays}

The extracts and the pure compounds were either dissolved or suspended in $0.2 \mathrm{~mL}$ dimethyl sulfoxide (DMSO)/100 mL water for molluscicidal assays and 0.5\% DMSO for brine shrimp and cercaricidal assays.

The methodology for molluscicidal assays was previously reported (Bilia et al., 2000 and Hostettmann et al., 1982). The experiment involves the immersion of Biomphalaria glabrata snails in an aqueous solution
(50 mL per snail) containing either the extracts or the compounds in appropriate concentrations for $24 \mathrm{~h}$. The snails were washed and transferred to recipients with distilled water and observed for $24 \mathrm{~h}$. Heartbeat was checked by microscope. Controls were prepared only with DMSO and distilled water $(0.2 \mathrm{~mL} / 100 \mathrm{~mL})$.

Snails infected with cercariae were exposed to artificial light for $3 \mathrm{~h}$ and the cercariae that released in this period are concentrated by their phototropism on the top of a recipient with destilled water made black on the base. The cercariae that were collected on graduated wells $(0.3 \mathrm{~mL})$ had the same emergence age. Approximately 60-80 freshly emitted cercariae were placed in each well and four wells for each concentration were tested. The organisms were observed on a stereoscopic microscope in after 15, 30 and 60 minutes. The isolated diterpene, kaurenoic acid, was tested at 400, 100 and $10 \mathrm{ppm}$ and controls group were prepared only with DMSO. Results are expressed in percentage in terms of destruction of the cercariae.

Brine shrimp eggs (Artemia salina Leach) were placed in seawater for $48 \mathrm{~h}$ before use. The eggs were placed in a two-compartment tank. One was covered to keep the eggs in the dark while the other was illuminated to attract shrimps through perforations on the boundary plate. After $24 \mathrm{~h}$, the phototropic shrimps, which went to the illuminated compartment, were collected by pipette and incubated under illumination for $24 \mathrm{~h}$ at room temperature (Harborne and Dey, 1991 and Lima et al., 2002; Silva et al., 2007; Nunes et al., 2008). Shrimps were added in groups of 10 organisms in four vials with final seawater volume of $5 \mathrm{~mL}$ per tested concentration. Preliminary bioassay was carried out with 1000, 100, and $10 \mathrm{ppm}$ after testing intermediate dosages. In order to verify the $A$. salina susceptibility, controls used only seawater or $0.5 \% \mathrm{DMSO} /$ seawater.

The colleted data was computerized to give $\mathrm{LC}_{10}$, $\mathrm{LC}_{50}$, and $\mathrm{LC}_{90}$ values determined by probit analysis.

\section{RESULTS AND DISCUSSION}

The $\mathrm{LC}_{10}, \mathrm{LC}_{50}$, and $\mathrm{LC}_{90}$ and corresponding

Table 1. Molluscicidal activity $\left(\mathrm{LC}_{10}, \mathrm{LC}_{50}\right.$, and $\mathrm{LC}_{90}$ ) of hexane $(\mathbf{A})$ and ethanol (B) leaf extracts and methanol bark extract $(\mathbf{C})$ of Croton floribundus and kaurenoic acid (1), on Biomphalaria glabrata snails, after $24 \mathrm{~h}$ of observation.

\begin{tabular}{l|cccc}
\hline \multirow{2}{*}{$\begin{array}{l}\text { Molluscicidal } \\
\text { activity }\end{array}$} & \multicolumn{4}{|c}{$\begin{array}{c}\text { Concentration of tested material } \\
(\mu \mathrm{g} / \mathrm{mL})\end{array}$} \\
\cline { 2 - 5 } & $\mathbf{A}$ & $\mathbf{B}$ & $\mathbf{C}$ & $\mathbf{1}^{*}$ \\
\hline $\mathrm{LC}_{10}$ & 7.6 & 1.8 & 0.43 & $0.50[0.17-2.44]$ \\
\hline $\mathrm{LC}_{50}$ & 37.4 & 14.8 & 4.2 & $1.16[0.96-3.22]$ \\
\hline $\mathrm{LC}_{90}$ & 85.2 & 35.2 & 11.5 & $4.28[2.34-13.9]$ \\
\hline
\end{tabular}

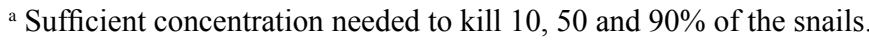

$*$ With confidence interval. $\left[\mathrm{CI}_{95}\right]=95 \%$ confidence interval. 
Table 2. Activity of different concentration of kaurenoic acid (1) on Schistosoma mansoni cercariae after 15, 30 and 60 minutes. Data are show as percentage (\%) of dead cercariae.

\begin{tabular}{lcccc}
\hline Duration of exposure & \multicolumn{3}{c}{ Concentration of 1} & Control group \\
& $400(\mu \mathrm{g} / \mathrm{mL})$ & $100(\mu \mathrm{g} / \mathrm{mL})$ & $10(\mu \mathrm{g} / \mathrm{mL})$ & \\
\hline $15 \mathrm{~min}$ & $100 *$ & $96.2[92.8-100]$ & $73.3[60.8-85.7]$ & $4.9[0.2-9.6]$ \\
$30 \mathrm{~min}$ & $100 *$ & $98.8[97.7-99.9]$ & $99.5[98.5-100]$ & $6.2[1.6-10.7]$ \\
$60 \mathrm{~min}$ & $100 *$ & $100 *$ & $100 *$ & $8.9[6.1-11.6]$ \\
\hline
\end{tabular}

Table 3. Toxicity $\left(\mathrm{LC}_{10}, \mathrm{LC}_{50}\right.$, and $\left.\mathrm{LC}_{90}\right)$ of hexane (A) and ethanol (B) leaf extracts and methanol bark extract (C) of Croton floribundus and kaurenoic acid (1), on Artemia salina Leach, after $24 \mathrm{~h}$ of observation.

\begin{tabular}{lcccc}
\hline Toxicity $^{\mathrm{a}}$ & \multicolumn{4}{c}{ Concentration of tested substances $(\mu \mathrm{g} / \mathrm{mL})$} \\
& $\mathbf{A}$ & $\mathbf{B}$ & $\mathbf{C}$ & $\mathbf{1}$ \\
\hline $\mathrm{LC}_{10}$ & $102.7[53.6-151.9]$ & $44.8[24.0-65.6]$ & $14.3[13.1-15.5]$ & $13.6[3.4-21.7]$ \\
$\mathrm{LC}_{50}$ & $481.5[436.3-526.7]$ & $230.7[173.3-302.2]$ & $237.7[216.2-259.3]$ & $659.7[540.3-779.0]$ \\
$\mathrm{LC}_{90}$ & $>1000$ & $881.6[847.0-916.2]$ & $>1000$ & $>1000$ \\
\hline
\end{tabular}

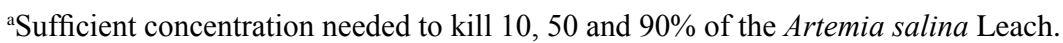

$\left[\mathrm{CI}_{95}\right]=95 \%$ confidence interval.

95\% confidence interval $\left[\mathrm{CI}_{95}\right]$ of organisms exposed for $24 \mathrm{~h}$ to Croton floribundus extracts and the isolated diterpenoid, kaurenoic acid, are given in Tables 1 and 3, and the results from cercaricidal assays are showed in Table 2.

Although the molluscicidal activity is widespread in the Euphorbiaceae family, the activity varies greatly from species to species and even between different parts of the same plant (Al-Zanbagi et al., 2000). The methanol extract of barks of $C$. floribundus showed high molluscicidal activity, $\mathrm{LC}_{50}$ at $4.2 \mathrm{ppm}$, and $\mathrm{LC}_{90}$ at $11.5 \mathrm{ppm}$ to Biomphalaria glabrata snails. This toxicity result is higher than others reported for other species of the Euphorbiaceae family, such as Jatropha glauca, Euphorbia helioscopia, and E. schimperiana (Al-Zanbagi et al., 2000), but neither so active as that of Euphorbia milli latex ( $\mathrm{LC}_{50} 0.12 \mathrm{ppm}$; Luna et al., 2005), which is already commonly used as molluscicides in several continents, nor that of niclosamide (BayluscideWP70 ${ }^{\circledR}$ ), with, LC $_{50} 0.077 \mathrm{ppm}$ (WHO 1993). Niclosamide is known to be acutely toxic to others species (Lima et al., 2002). None of the snails in the control group died or showed significant behavioral changes.

Artemia salina Leach., known as brine shrimp, is a small seawater crustacean. A. salina larvae lethality assay is considered to be the most useful for the preliminary assessment of general activity, and the toxicity bioassays have show correlation with some cytotoxic and pesticide activities (Harborne and Dey, 1991; Shoeb et al., 2007; Subhan et al., 2008). In this work, the $A$. salina bioassays were performed to evaluate the toxicity of Croton floribundus extracts and kaurenoic acid against non-target organisms.

Compound 1 (Figure 1) present high activity against Schistosoma mansoni cercariae, killing most of the organisms, $99.5 \%$ in 30 minutes, at 10 ppm (Table 2) and high molluscicidal activity and low toxicity for a non-target specie, A. salina Leach.

All Croton floribundus extracts and the isolated compound, kaurenoic acid, exhibited high molluscicidal activity and low lethality against non-target species, Artemia salina Leach. C. floribundus extracts present acute toxicity at $\mathrm{LC}_{50}$ within $230-481 \mathrm{ppm}$ (Table 3), while $\mathrm{LC}_{50}$ of Euphorbia milli against Brine shrimp larvae was 24 ppm (Oliveira-Filho and Paumgarttem, 2000).

Two derivatives of kaurenoic acid were synthesized to investigate the structure/molluscicidal activity relationship, one with a methoxyl group on the double bond, 16-methoxy ent-kauran-19-oic acid (2), and another with an ester on the carboxyl group, methyl ent-kaur-16-en-19-oate (3) (Figure 1). Derivative 2 was subjected to molluscicidal evaluation at 10 and $2 \mathrm{ppm}$ and showed very similar activity to that of kaurenoic acid, while derivative $\mathbf{3}$ did not exhibit any activity at the same concentrations. These experimental data suggest that the $\mathrm{COOH}$ group has an important relation with the molluscicidal activity of kaurenoic acid, in accordance with the observed for bidesmosidic triterpenic saponins, which have the $\mathrm{COOH}$ group esterified with sugar and no molluscicidal activity, while the monodesmosidics with $\mathrm{COOH}$ group are molluscicidal agents (Ndamba et al., 1994). Other investigations with kaurenoic acid derivatives showed that antifungal activity 


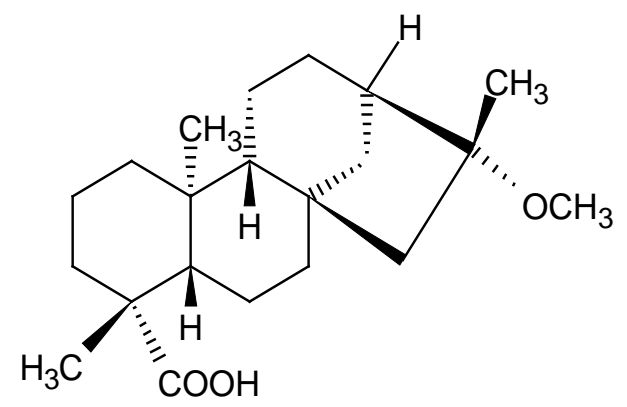

1<smiles>C=C1CC[C@H]2[C@]3(C)CCC[C@@]4(C)C[C@@]2(CC[C@]43C(=O)OC)C1</smiles>

2<smiles>C=C1CC[C@@H]2[C@]3(C)CCC[C@@]4(C)C[C@@]2(CC[C@]43C(=O)O)C1</smiles>

3

Figure 1. Structures of compounds 1, 2 and 3.

(Boeck et al., 2005), and trypanocidal activity (Batista et al., 2007; Saúde-Guimarães \& Faria, 2007) have relation with this group too.

The results observed indicate that the leaves and bark of $C$. floribundus present potent mosllucici dal agents. The activities of the leaf extracts are of interest, as they do not require killing the tree as debarking would.

\section{ACKNOWLEDGMENTS}

The authors are grateful to Prof. Dr. Maria Conceição de Souza for the botanical identification on the plant material used. One of us (J. M.Medina) is grateful to CAPES-Brazil for doctoral fellowship.

\section{REFERENCES}

Al-Zanbagi NA, Banaja AA, Barret J 2000. Molluscicidal activity of some Saudi Arabian Euphorbiales against snail Biomphalaria pfeifferi. J Ethnopharmacol 70: 119-125.

Batista R, Humberto JL, Chiari E, Oliveira AB 2007. Synthesis and trypanocidal activity of ent-kaurane glycosides. Bioorg Med Chem 15: 381-391.

Bilia AR, Braca A, Mendez J, Morelli I 2000. Molluscicidal and piscicidal activities of Venezuelan Chrysobalanaceae plants. Pharmacol Lett 66: 53-59.

Boeck P, Sá MM, Souza BS, Cercená R, Escalante AM, Zachino SA, Cechinel Filho V, Yunes RA 2005. A simple synthesis of kaurenoic esters and other derivatives and evaluation of their antifungal activity. $\mathrm{J} \mathrm{Braz} \mathrm{Chem}$ Soc 16: 1360-1366.

Correa MP 1984. Dicionário das plantas úteis do Brasil e das exóticas cultivadas. Imprensa nacional, Rio de Janeiro: Vol. 1, p.503-504.

Ghisalberti EL 1997. The biological activity of naturally occuring kaurane diterpenes. Fitoterapia 68: 303-325.

Harborne JB, Dey PM 1991. Methods in plant biochemistry. Assays for bioactivity. Academic press, London: Vol. 6, p. 8-10.

Hostettmann K, Kizu H, Tomimori T 1982. Molluscicidal properties of various saponins. Planta Med 44: 34-35.

Lima NMF, Santos AF, Porfírio Z, Goulart OF, Sant'Ana AEG 2002. Toxicity of lapachol and isolapachol and their potassium salt against Biomphalaria glabrata, Schistosoma mansoni cercarie, Artemia salina and Tilapia nilotica. Acta Tropica 83: 43-47.

Luna JS, Santos AF, Lima MRF, Omena MC, Mendonça FAC, Bieber LW, Sant'Ana AEG 2005. A study of larvicidal and molluscicidal activities of some medicinal plants from Northeast Brazil. J Ethnopharmacol 97: 199206.

Marston A, Hostettmann K 1993. Search for antifugal, molluscicidal and larvicidal compounds from African medicinal plants. J Ethnopharmacol 38: 215-223.

Ndamba J, Lemmich E, Molgaad P 1994. Release of molluscicidal saponins from Phytolacca dodecandra aqueous berry extracts as influenced by the male plant and the extraction procedure. Biochem Syst Ecol 22: 249-257.

Nunes XP, Mesquita RF, Silva DA, Lira DP, Costa VCO, Silva MVB, Xavier AL, Diniz MFFM, Agra MF 2008. Constituintes químicos, avaliação das atividades citotóxica e antioxidante de Mimosa paraibana Barneby (Mimosaceae). Rev Bras Farmacogn 18 (Supl): 718-723.

Oliveira-Filho EC, Paumgartten FJR 2000. Toxicity of Euphorbia milli latex and niclosamide to snails and non-target aquatic species. Ecotox Environ Safe 46: 342-350.

Oliveira AM, Humberto MMS, Silva JM, Rocha RFA, Sant'Ana AEG 2006. Estudo fitoquímico e avaliação das atividades moluscicida e larvicida dos extratos da casca do caule e folha de Eugenia malaccensis L. (Myrtaceae). Rev Bras Farmacogn 16 (Supl.): 618624.

Saúde-Guimarães DA, Faria AR 2007. Substâncias da natureza com atividade anti-Trypanosoma cruzi. Rev Bras Farmacogn 17: 455-465.

Shoeb M, MacManus SM, Jaspars M, Kong-Thoo-Lin P, Nahar L, Celik S, Sarker SD 2007. Bioactivity of two Turkish endemic Centaurea species, and their major constituents. Rev Bras Farmacogn 17: 155-159.

Silva TMS, Nascimento RJB, Batista MM, Agra MF, Camara CA 2007. Brine shrimp bioassay of some species 
of Solanum from Northestern Brazil. Rev Bras Farmacogn 17: 35-38.

Sousa PJC, Barros CAL, Rocha JCS, Lira DS, Monteiro GM, Maia JGS 2008. Avaliação toxicológica do óleo essencial de Piper aduncum L. Rev Bras Farmacogn 18: 217-221

Subhan N, Alam MA, Ahmed F, Shahid IJ, Nahar L, Sarker SD 2008. Bioactivity of Excoecaria agallocha. Rev Bras Farmacogn 18: 521-526.

WHO 1993. World Health Organization. The control of schistosomiasis. Second report of WHO expert committee. Geneva: World Health Organization, 1993. WHO Technical Report Series, No. 830. 